\title{
Plant Breeders' Rights Licensing in Smallholder Farming: Observations From Kenya
}

\author{
Peter Munyi ${ }^{1}$, Bram De Jonge ${ }^{2} \&$ Neils Louwaars ${ }^{3}$ \\ ${ }^{1}$ Law and Governance Group, Wageningen University \& Research, the Netherlands; University of Nairobi \\ School of Law, Kenya \\ ${ }^{2}$ Law and Governance Group, Wageningen University \& Research, the Netherlands; IP Unit, University of Cape \\ Town, South Africa \\ ${ }^{3}$ Plantum NL, the Netherlands; Law and Governance Group, Wageningen University \& Research, the \\ Netherlands \\ Correspondence: Peter Munyi, Law and Governance Group, Wageningen University \& Research, the \\ Netherlands; University of Nairobi School of Law, Kenya. E-mail: gitahimunyi@gmail.com
}

Received: November 14, $2017 \quad$ Accepted: January 3, $2018 \quad$ Online Published: May 31, 2018

doi:10.5539/jpl.v11n2p45

URL: https://doi.org/10.5539/jpl.v11n2p45

\begin{abstract}
Focusing on Kenya as an example of a market where food production is mostly for subsistence purposes, this article seeks to establish whether licensing of plant breeders' rights is a mechanism that can facilitate access to seeds and planting material to smallholder farmers. Through a case study method and qualitative interviews of a wide range of stakeholders, it was found that licensing strategies that are employed in market conditions such as those prevailing in Kenya usually involve some form of market differentiation. This is in order to ensure that the targeted beneficiary is reached. It was also found that whatever licensing strategy is employed, each has some advantages and disadvantages. Further, not-for-profit technology brokers have emerged with a view to absorb some costs in the licensing process which are otherwise out of reach for smallholder farmers. Breeders also waive some of their rights with respect to protected varieties. The article concludes that the use of licensing as a tool to facilitate access to seeds and planting material for smallholder farmers in market conditions such as those prevailing in Kenya has received little attention and only involves very few commercial crops. Where breeders choose to waive some of their rights, they should let farmers know so as to create legal certainty on utilization of accessed varieties.
\end{abstract}

Keywords: seeds, licensing, plant breeders' rights

\section{Introduction}

Licensing is the most common vehicle by which intellectual property rights (IPRs) are transferred from inventors to users (Payumo, grimes \& Jones, 2012). As inventors, plant breeders utilize licensing as a tool for introduction of protected varieties of plants. This is preconditioned upon plant breeders' rights also known as plant varieties protection (PVP) being taken out by the breeder against the new variety. As plant breeding is part of an innovation chain reaching from fundamental research through to the production and marketing of seed and planting material it therefore follows that the process through which breeders introduce new varieties of seeds and planting material to farmers is often not direct (Louwaars, et al, 2009). This process normally involves a number of intermediaries in the seed enterprise such as seed multipliers, dealers and stockists.

As plant breeders' rights constitute a set of private rights conferred to a breeder, licences then are contracts between parties. However, licence agreements are not the only contracts that a breeder may enter into in relation to a protected variety. Other contracts may include material transfer agreements in relation to accessing varietal material for research purposes, and seed production agreements where a breeder contracts a third party in multiplication of seed.

Licence agreements are tools normally deployed in commercial agricultural settings, where crop production is targeted for sale in markets, and not for subsistence purposes. In these settings, plant breeding is according to the International Union for the Protection of New Varieties of Plants (UPOV) (2008), usually private sector-led and licence agreements could comprise almost all rights of the breeder, or can be limited to certain acts or 'uses' 
and/or territories. Whether one licensing mechanism is applied as opposed to another in managing breeder strategies varies depending on various factors including (i) the general legal structure of the national plant breeder's rights system (ii) source of, and policies attendant to the income for the breeder (iii) type and market of crop, including the seed system operating, and (iv) royalties collection mechanisms that may be available to the breeder.

Kenya's economy is agriculture driven. It provides employment to over $75 \%$ of the population and contributes up to $25 \%$ of the country's gross domestic product (Devarajan \& Kasekende, 2011). Compared to other African countries such as Morocco and Tunisia (and except for South Africa) Kenya has for the last 15 years had a fairly vibrant plant breeders' rights registration system (Note 1). As at 1 February 2013, 1,158 applications for grants of plant breeders' rights had been filed through the system, with ornamental crops accounting for over $60 \%$ of the applications, and food crops 34\% (Munyi, 2015). The plant breeders' rights registration system notwithstanding, Kenya's domestic seeds market is relatively small. In 2011, the International Seed Federation (ISF) estimated this market to stand at USD 60 million as compared to Morocco's at USD 140 million, and South Africa's at USD 454 million. Most farmers access seed from informal sources (Ayieko \& Tschirely, 2006). The 2010 National Seed Policy buttresses this fact by acknowledging that whereas the source and quality of seed obtained by the informal seed sector may not be known, it is the major source of planting material for the farmers.

Whether a variety is protected or not, a key feature of the domestic seed market for new varieties in Kenya is that the commercial market for most crops-except in horticulture, is very small as the predominant group of farmers has low purchasing power. Breeders and breeding companies in Kenya are operating in a market environment where most farmers are poor and do not invest in purchased seed when other acceptable sources exist. This market condition cannot be ignored and has to be taken into account when breeders consider their licensing strategies.

Taking into account the market conditions prevailing in Kenya, this article analyses whether licensing of plant breeders' rights is a mechanism that can facilitate access to seeds and planting material to smallholder farmers. In answering this question, the article begins by examining factors that influence breeder licensing strategies. The factors considered are those that cut across all market conditions that a breeder is confronted with-from strong commercial export markets to settings (such as in Kenya) where food crop farming is normally for subsistence purposes and seed saving and exchange between farmers is prevalent. Thereafter, three Kenyan seeds licensing cases in the food crops sector are described. In choosing these cases it is recognized that the food crops involved are not only grown for commercial and subsistence purposes but also that plant breeders' rights have or are being taken out for these crops either in Kenya or elsewhere. Licensing conditions and strategies that emerge from these three cases provide a basis for discussions whether and how licensing of plant breeders' rights can be a tool to facilitate access to seeds and planting material for smallholder farmers. Thereafter a conclusion follows.

The subject matter of this article is among the first scholarly articles that address licensing of plant breeders' rights in relation to smallholder famers. Most of the scholarly work and studies in this area such as that by Lybbert (2002) address agricultural biotechnology licensing for smallholder farmers from a patents, not plant breeders' rights perspective. As such not much literature on the subject matter of this article exists.

In undertaking this study, the authors conducted qualitative interviews over a period of three years amongst a wide range of stakeholders. These included policy makers; seed companies; seed traders; seed associations; seed multipliers; commercial and smallholder farmers; public and private sector plant breeders; agricultural technology brokers; researchers and scientists in agricultural research centres of the Consultative Group on International Agricultural Research (CGIAR); officials of the International Union for Protection of New Varieties of Plants (UPOV); and, non-governmental organizations. Additional data is complemented through literature review, and discussions during workshops held in Kenya, South Africa and the Netherlands where preliminary data were discussed.

\section{Factors That Influence Breeder Licensing Strategies}

As a private arrangement between the breeder and other parties, licensing is first and foremost a business decision. Therefore factors that affect licensing are essentially dependent upon strategic decisions the breeder takes with a view to enable a variety reach as many farmers as possible, at the right price and, at the right time. A commercial breeder may thus optimise profits or have other commercial goals. For a public breeder outreach to farmers may be the first development goal, but royalty income may also play an increasing role depending on institution policies. From research undertaken by the authors, it appears that the following are some of the factors that affect licensing strategies: (i) the general legal structure of the national plant breeder's rights system, (ii) 
source of, and policies attendant to the income for the breeder (iii) type and market of crop, including the seed system operating, and (iv) royalties collection mechanisms that may be available to the breeder.

\subsection{The General Legal Structure of the National Plant Breeder's Right System}

A plant breeders' rights system provides the basis upon which rights are granted and enforced. The system consists not only of the rules granting the rights but also the institution administering these rights, as the efficiency with which the rights of a breeder are responded to is important.

Where a country is a member of UPOV whether its plant breeders' rights system is based on UPOV 1978 or UPOV 1991 Conventions is an important consideration for a breeder in crafting a licensing strategy for the market in that specific country. This is because the rights and exceptions to the rights granted to a breeder within each of these two UPOV Conventions differ. For example, under a UPOV 1978 Convention-based plant breeders' rights system, farmers may save, re-use, exchange and, for small quantities, even sell farm-saved seed of protected varieties obtained from their own harvests. However, under a UPOV 199 Convention-based plant breeders' rights system, the use by a farmer of the product of the harvest of a protected variety for propagating purposes may be allowed but only within reasonable limits and subject to the safeguarding of the legitimate interests of the breeder (Note 2). This means that the farmer can only use farm-saved seed of a protected variety on his own holdings, while exchange and local trade of farm-saved seed amongst farmers is forbidden. Also, a farmer who plants farm-saved seed on his own holding may have to pay a (reduced) royalty to the breeder. This is referred to as the farmer's privilege (Note 3). There is another compulsory exception under UPOV 1991 Convention for acts done privately and for non-commercial purposes. While this exception is not further defined, on its website UPOV has published a FAQ stating that "Contracting parties have the flexibility to consider, where the legitimate interest of the breeders are not significantly affected, in the occasional case of propagating material of protected varieties, allowing subsistence farmers to exchange this against other vital goods within the local community."

These differences between UPOV 1978 and UPOV 1991 Conventions, and, in particular, the way the relevant provisions are legislated and implemented on the national level, dictate the precise nature of the plant breeders' rights legislation in a country. This in turn dictates whether or not plant breeders in a UPOV member country have the necessary legal means to enable collection of royalties particularly for farm-saved seed (Curtis \& Nilsson, 2012).

In Kenya, the general legal structure of the plant breeders' rights system is founded upon the Constitution. This constitutional basis then gives anchorage to the statutory framework for its implementation, including enforcement. Two statutes-the 1972 Seeds and Plant Varieties Act ('the SPVA') and the 2012 Seeds and Plant Varieties (Amendment) Act ('the 2012 SPVA Amendment') deal with the substance of grants of plant breeders' rights. A third statute-the Anti Counterfeiting Act, 2008 complements the SPVA and the 2012 SPVA Amendment in enforcement of plant breeders' rights in instances where it is considered that counterfeiting of protected varieties has taken place. The body that administers plant breeders' rights-the Kenya Plant Health Inspectorate Service (KEPHIS), is established through complementary legislation as its functions extend beyond plant breeders' rights to include seed certification and phytosanitary matters (Note 4).

On establishment, Kenya's plant breeders' rights system was based on UPOV 1978 Convention. It has since been upgraded through the 2012 SPVA Amendment, in its aspiration to conform to UPOV 1991 Convention, which has not quite been achieved. The upgraded legislation does not for example, provide for private and non-commercial use exception, which is a compulsory exception under UPOV 1991 Convention. While the legislation provides for the farmer's privilege exception in wording exactly similar to that in UPOV 1991 Convention, no regulation has been put in place to facilitate implementation of this provision. As Kenya is a party to the African Regional Intellectual Property Organization (ARIPO), it is also likely that should the country ratify the Arusha Protocol for the Protection of New Varieties of Plants, then should this regional plant breeders' rights system come into force, it will also become available in Kenya (Note 5).

Related to the presence of the rules on plant breeders' rights themselves is the overall effectiveness of the institutions responsible for administration of these rules. The institution responsible for grant of plant breeders' rights is required to be efficient and effective in this process, as well as its involvement in enforcement actions, should this be necessary. In Kenya, KEPHIS is the responsible institution for grant of plant breeders' rights. Whereas it is considered to be efficient and effective in dealing with applications and grants of plant breeders' rights, a perception exists that it may not be robust, particularly in making available information necessary to enable a breeder pursue infringement actions, notwithstanding that. This is attributed to the fact that at the national level, the legislation on access to information that would obligate KEPHIS to provide relevant 
information in its possession is all too new, notwithstanding constitutional recognition of this right. Some breeders therefore consider that access to information such as data on varietal certification quantities from KEPHIS may not be with ease.

The overall effectiveness and efficiency of both the plant breeders' rights system and its attendant institutions as well as other ancillary institutions such as courts are key considerations in the determination by breeders of the choice of law of contract of the country that will apply in interpreting licence agreements. In choosing the law of contract of the country in which a licence agreement will be interpreted and enforced, the breeder must be aware of the totality of legal tools made available by the law of the country. Curtis and Nilsson (2012) have found that plant breeders in different countries adopt different attitudes to the enforcement of their rights and this leads to widely differing policies and strategies in the collection of royalties from farm-saved seeds. The tools available to assist collection of royalties may include obligations on farmers to provide information on the seed they have saved, certification systems and penalties for evasion of royalty payments (Curtis \& Nilsson, 2012).

Taking the case of the breeders in the ornamental crops sector that are operating in Kenya, the licences issued would mostly provide for the choice of law of contract applicable being a European jurisdiction-mostly the Netherlands as breeders hold the view that Dutch law of contract affords them more legal tools for enforcement than Kenyan law of contract. This is not surprising also given that most of the Kenyan licensors in the ornamental crops sector are of Dutch if not European origin. On the other hand, AATF licences in the WEMA project (discussed in section 3.1 below) stipulate that the applicable law of contract is that of England and Wales, notwithstanding that all parties (including AATF) entering into the licence agreements may all be based in Kenya, if not in Africa. An outcome of this choice is that the law of contract of the country that is not selected then becomes irrelevant to the extent that it is not applicable in governing licensing relationships between parties.

The nature and effectiveness of the plant breeders' rights system in place is therefore an important consideration for a breeder in laying out a licensing strategy. Whether the plant breeders' rights system is based on UPOV 1978 Convention or UPOV 1991 Convention dictates the stack of rights available not only to the breeder but also to the farmer. To implement a smallholder farmer-focussed breeding strategy, a breeder may for example, have to forgo some of his rights where such a strategy is implemented in a UPOV 1991 Convention-based plant breeders' rights environment.

\subsection{Source of, and Policies Attendant to the Income for the Breeder}

The breeder landscape in Kenya consists of public and private institutions. Within the public institutions are two main categories: national agricultural research centres; public universities; and, state owned seed companies on the one hand, and, the international agricultural centres of the CGIAR on the other. As regards private institutions, these are comprised of international seed companies in the food crops, vegetables and floricultural sectors, and national seed companies participating more in seed multiplication than plant breeding.

For national public institutions undertaking plant breeding activities, the source and policies attendant to the funding, and breeder income is important. Except for instances where these institutions engage in contract research for which funding may be from private sources, often they rely on public funding. Kaul (1999) and Muraguri (2010) posit that use of public funds in research and development brings about two things: the first, is the notion that the resultant product following use of these funds is often considered a public good, which should be available and accessible to all. Secondly, the use of public funds is usually subject to wider policy directions and limitations such as rural development and smallholder farmers' needs that may be set out either by statute or institutional mandates, particularly on ownership and deployment of these research results. Next to that there may be policy directions on obtaining and managing intellectual property. The United States Bayh-Dole Act (1980), which among others allows private and public institutions to own inventions developed with federal funding unlike in the past when such inventions were assigned to the government, is one typical statutory example. Another example is the South African Intellectual Property from Publicly Financed Research and Development Act (2008), which requires among others, that publicly funded research must be used and commercialised for the benefit of South Africans. The enactment of the Bayh-Dole Act led to a sharp increase in the number of public institutions taking out patents and other IPRs on the results of their research thereafter leading to launching of technology commercialization and licensing programmes (Graff \& Bennett, 2007). The South African statute has led to some of the public institutions such as the Agricultural Research Council instituting technology deployment policies with a view to include participation of smallholder farmers, for example in citrus value chains.

In Kenya, whereas there is no statutory or other national policy explicitly dealing with stewardship of publicly funded research results. Public funded institutions, by a combination of statutes and subject to institutional 
policies, own IPRs generated by them. Whether these IPRs may be used for the benefit of the public is according to the Science, Technology and Innovation Act (2013) left to institutional discretion. The University of Nairobi's intellectual property policy is an apt example. The object of the policy of this public institution is to make intellectual property "available to industry and others for the public benefit, while providing recognition to individual inventors and encouraging the prompt and open dissemination of research results." This objective appears to be in line with Science, Technology and Innovation Act (2013) whose section 25 vests all rights in any inventions in respect of processes, apparatus and machines made on behalf of an institution to the institution, and leaves the availability of such inventions to the public to the discretion of the institution.

For international agricultural centres of the CGIAR their main mandate is the production of public goods. The CGIAR Principles on the Management of Intellectual Assets (2012) allow Centres to grant limited exclusivity for commercialization, and to apply for patents or plant variety protection over their intellectual assets, but only if "necessary for the further improvement of such Intellectual Assets or to enhance the scale or scope of impact on target beneficiaries, in furtherance of the CGIAR Vision". This is to facilitate collaboration with the private sector while safeguarding the international public goods nature of the results of its research and development activities.

As for private entities undertaking breeding activities, the primary source of breeder research funding is usually internal. Therefore company policies relating to the overall business strategies-including public image and sustainability issues determine how these resources are deployed taking into account the need to maximize returns to the owners or shareholders. Company policies may also include commitments and strategies to help improve the situation of smallholder farmers, based on their portfolio, assets and capabilities. One initiative that aims to make this transparent is the Access to Seeds Index, which measures and compares the efforts of the world's leading seed companies to enhance the productivity of smallholder farmers. What emerges however, is that at the core of all these strategies is the fact that breeding companies have to look at a product development horizon of several to many years. It may take 4-6 years to bring a new maize or tomato hybrid to market, and 12 to dozens of years for potato or fruit trees (Note 6). However, new breeding technologies continue to emerge that may variedly reduce product development horizons between crops.

From the above, it is apparent that where a breeder institution, whether private or public puts in place a smallholder farmer-focused breeding policy, implementation of a such a policy would be confronted with considerations such as institutional and individual income and investor returns. These considerations have to be taken into account by the breeder in determining licensing strategies to employ in order to effect the policy.

\subsection{Type and Market of Crop, Including the Seed System Operating}

How a crop is propagated is important in determining the licensing strategy to be deployed. In Kenya, a wide range of crops is cultivated: hybrids; open pollinated varieties (OPVs); and vegetatively propagated crops (VPCs).

Taking the case of maize whose seed is produced by private and public actors, both hybrid seeds and open pollinated varieties (OPVs) are available in the market. Hybrid varieties are made by crossing selected parents (often inbred lines) while OPVs are broad populations created whether by crossing many known parents (synthetics), or by recurrent selection in freely pollinating populations (Setimela \& Kosina, 2006). There are a number of advantages and disadvantages to growing each. Setimela and Kosina (2006) observe that OPVs show greater variability than hybrids, their seeds may also be saved for re-planting without much yield loss. Further, hybrids are characteristically higher yielding than OPVs, but generally require much higher standards of field management than OPVs to achieve their yield potential. Thus because seed saved from hybrid harvests are low yielding, seed saving is not usually a concern for hybrid maize breeders. When plant breeders' rights are taken out in respect of hybrids it is the inbred lines of these varieties that are usually protected along with the hybrid itself. For OPVs the end product, the OP-variety is protected. Licensing of plant breeders' rights may then take different forms. For example, a licence may be given to produce the hybrid and in some cases the multiplication of the inbreds. A seed producer may also be licensed to multiply one parent but is sold the other. That way quantities produced can be controlled particularly when the second parent is a hybrid itself (three-way cross).

For vegetatively propagated crops (VPCs) such as potato, evidence is abound that over $95 \%$ of seed in Kenya is obtained from informal channels (Ayieko \& Tschirely, 2006). This is in part because there is basically no genetic difference between the crop harvested and seed production. Seed potatoes are also bulky and transportation often is a problem, particularly in areas where road infrastructure is not available or poor. For potato breeders even where plant breeders' rights are taken out, controlling the crop value chain is important as well. This is to increase opportunities for collecting royalties on the use and sale of farm-saved seed of the protected varieties by 
third parties. In Kenya, foreign private breeders are gradually introducing their varieties, taking caution to ensure that the task of controlling the value chain is passed on to local intermediaries or, if that is not possible, by collecting royalty payments only from the first cycle of seed production.

Most of the licensing of protected plant varieties that is occurring in Kenya relates to ornamental crops, mainly cuttings and bedding plants. Given that over $60 \%$ of all plant varieties protected are ornamental plants, this is not surprising. Furthermore, as ornamental growers multiply the basic stock obtained from the breeder, licensing is a necessary tool for controlling the ornamentals value chain. In this sector, the main strategy breeders employ is licensing varieties to a single agent (as opposed to multiple agents) who in turn, sub-licences the varieties to the growers. That agent is then bestowed with the responsibility of collecting royalties from the growers and remitting the same to the breeder. The centralized nature of the ornamental crops market is an enabler for the value chain to be closely controlled.

Seed systems operating with respect to a particular crop are also a factor to be considered. Munyi and De Jonge (2015) have identified at least six seed systems to operate in Kenya- farmer based seed systems; community-based seed systems; relief-based seed systems; public formal systems; mixed private public seed systems; pure private seed systems and, closed value chains. Different crops may fall under different seed systems, some crops operating in more than one. A farmer is likely to participate in different seed systems depending on the number of crops under cultivation on his land holding. For example, a farmer may receive seed as a contract grower in respect of a cash crop such as tobacco (closed value chain); buy maize seed from a local seed trader (mixed public private seed system); buy tomato seed directly from a multinational seed company (pure private seed system); and use farm-saved planting materials for growing some cassava (farmer based seed system).

For a breeder whose plant variety can easily be disseminated through the use and exchange of farm-saved seed in a farmer-based seed system such as OPV maize and for a number of potato varieties, there is a tendency to either licence these varieties to the seed producers on a royalty-free basis or to purely not licence them at all but multiply and sell the seed to the market at the lowest cost possible (Note 7). For closed value chains and some pure private seed systems, the seed markets are well organized and the breeder is able to control the value chain for the seed and may therefore employ a different strategy such as exclusive licensing to a single agent who in turn sub-licences the varieties. This is the case with ornamental crops discussed above. In relief seed supplies and community based seed systems, the breeder is normally hardly involved in these systems and may, for example, be requested to provide royalty free licences for multiplication of seed with a view to replenish varietal stock following a calamity such as drought or plant disease burden. While licensing per se is not normally taking place in these seed systems, authority to exclusively multiply seeds may be granted in order to ensure that the quality of the seed reaching the farmer is maintained. An example here is cassava where under the Great Lakes Cassava Initiative (GLCI) few farmers in western Kenya have been trained by an NGO-Catholic Relief Services (CRS) to multiply disease-free cassava cuttings for others (Note 8).

Type and market for a crop, including the seed system the crop operates in are important factors for consideration in breeder licensing strategies. Some types of crops are easily reproducible making plant breeders' rights important in steering access to protected material. Markets for crops and the seed systems the crops operate in also influence actions that farmers will take to access seed.

\subsection{Royalties Collection Mechanisms That May Be Available to the Breeder}

Royalties provide the main mechanism through which a breeder recoups his investments on the protected variety. Even in instances where a farmer, through exploitation of the farmers privilege exception saves and reuses seed from his own harvest, on his own holdings (farm saved seeds), in some situations which vary from country to country, a reasonable payment is to be made to the breeder. This article discusses royalties collection mechanisms arising both from commercial seed production and farm-saved seeds of protected varieties.

A variety of royalty collection mechanisms exist. These include extended royalties system (ERS), end-point royalties system (EPR) and others pegged upon units of cuttings or area propagated with the crop in question. All these royalty collection systems find their foundational basis on a PBR law, backed by contractual arrangements, through licensing agreements. An ERS system when applied to certified or protected varieties operates in the form of a licence agreement with a payment being made at the point of sale of seed. An ERS system is very efficient in collecting royalties for certified seed, but this efficiency is eroded significantly in collecting royalties from farm-saved seed, especially in situations where either it is in the law, or, farmers believe that it is within their right, to save and re-use seeds without compensating the breeder (Curtis \& Nilsson, 2012). With respect to EPR systems, these concern collecting royalties not at the point of sale of the seed, but rather at the point of 
selling the harvest arising from the seed. EPR systems are therefore very efficient in collecting royalties for harvests whose markets are highly organized and centralized, and a culture of varietal declaration at the point of delivery to the market exists (Curtis \& Nilsson, 2012). The Australian grain market is one example where an EPR system has been very efficient in collecting royalties for protected varieties and farm-saved seeds (Thomson, 2013). ERS and EPR systems are mostly used to collect royalties in cereals crops. As regards royalties collections based on units of cuttings or areas cultivated with a particular crop, this system is according to Royalties Administration International mostly used for ornamental crops, backed by licensing agreements and market surveillance mechanisms to confirm actual areas planted with the crop, or units planted. Some mechanisms such as EPR carry more risks than upfront payment systems as in the former, the royalty payable is proportionate to the crop harvest while in the latter, it is simply pegged on seed sales. The risk notwithstanding, EPR are also considered to be equitable to the extent that they capture the whole market. Therefore even harvests produced from farm-saved seed do not escape the royalties net (Grain SA, 2015).

Cereal crops and VPCs present the most dilemma to a breeder in determining the most appropriate royalty collection mechanism as morphologically, seeds for these crops are very similar to their harvests. Therefore, seed saving is easy for these crops, with the exception of hybrid varieties. How then a breeder decides the appropriate mechanism to employ in collecting royalties varies from market to market. For crops whose markets are well structured and centralized, breeders have the freedom to choose whichever mechanism is most preferable.

Royalties collection being a private activity it behoves the breeder to be organised enough in the market place. Breeder associations, seed producers associations and farmer producers co-operatives therefore play a key role in facilitating royalties collection. In France, South Africa and the United Kingdom, SICASOV, the South African National Seed Organisation (SANSOR) and Grain SA; and, the British Society of Plant Breeders are respectively, instrumental in organizing royalties collecting mechanisms for grain crops whether from certified or farm-saved seed. This situation generally remains in most countries with long established plant breeders' rights systems.

Experiences in collection of breeder royalties for protected varieties in Kenya can be found in both the ornamental crops and food crops sectors. The ornamental crops sector produces mostly for the export market, which is well structured. Breeders in this sector who are predominantly foreign employ global agents such as Royalty Administration International in licensing their protected varieties and collecting royalties from licensees. Incidences of payments default are low as surveillance throughout the supply chain is possible. With food crops, experience in licensing and subsequent collections of royalties, revolves mainly around KARI (now part of KALRO) as the licensor. Initially, KARI had an exclusive licensing agreement with Kenya Seed Company, a state-owned agency with authority to further sub-licence varieties to other companies. However, in implementing the KARI Strategic Plan 2005-2015, this model was abandoned, with KARI establishing a seed unit to promote own technologies and maximize revenue (Rangnekar, 201). Concurrent with establishing a seed unit was also adoption of non-exclusive licensing models for different crops, with beneficiary licensees either making upfront payments for seeds, or paying royalties based on gross sales on an annual basis- a combination of ERS and EPR (Thornstrom, Virgin, Thorn \& Ericsson, 2013).

Use of seed trader associations, breeder associations and centralized markets for grains and cereals especially, in royalty collection mechanisms is hardly present in Kenya. This can be attributed to three reasons: first, except for very few seed companies, most are involved in seed multiplication activities, not plant breeding and therefore do not own varieties themselves. Therefore even as self-organized as they are through the Seed Traders Association of Kenya (STAK), royalties collection is not one of the priority issues for consideration by seed companies. Secondly, most plant breeders are employees of public institutions- KALRO, Kenya Seed Company or public universities. Debate on whether public plant breeders as salaried employees, should be receiving additional compensation for developing new and protected varieties has been ensuing for years and is yet to be settled. As such the national breeders association- Plant Breeders Association of Kenya (PBAK), is not mandated to collect royalties on behalf of the owners of the varieties, that is the public institutions themselves. Thirdly, markets for most crops are poorly structured and co-ordinated. The National Cereals and Produce Board, another state agency with the mandate to provide a ready market for grain crops is not efficient in providing farm inputs and guaranteeing markets for harvests. The overall appearance is on there being more priority and emphasis in controlling the quality of seed available in the market, and less on creating efficient seed market channels. As such there are multiple and uncoordinated marketing strategies for seed by various seed producers. These strategies are not effective to enable collection of end-point royalties, mainly because registration of the source of the variety for which royalties could be collected from the harvested product at the point of sale is not a requirement.

One factor that has emerged in royalties collection is the perceived role of government through a state agency- 
the Agriculture and Food Authority (AFA) in this process. Whereas royalties collection is intended to be a private activity, through section 6(1) of the Crops Act, 2013 AFA is given responsibility to among others "charging of ...breeder royalties on all scheduled crops..." While AFA is yet to commence implementation of this provision, this would clearly give owners of protected varieties a helping hand in collection of royalties. Whether this helping hand will be extended to all owners of protected varieties and if so, how, remains to be seen suffice to say it is an important factor to consider in royalties collection processes in the future.

Royalties provide one of the basic tools through which a breeder recoups investments. Mechanisms that may be available for collection of seed royalties from farmers are a useful consideration to be had by a breeder, and these may have an influence on how licensing of protected material occurs, as between the breeder and other intermediaries.

The totality of the factors stated above all influence in one way or another, the plant breeders' rights licensing strategy a breeder takes in order to make a variety available. In countries where the commercial seed market is not well developed, these factors are extra important as obtaining returns on investments is not necessarily assured. Yet, whereas licensing strategies are normally aimed at recouping breeders' investments in the protected variety, this article aims to explore whether licensing of plant breeders' rights can also be a tool to facilitate access to seeds and planting material to smallholder farmers. We will do so by presenting and analyzing three specific licensing examples in Kenya in the remainder of this article.

\section{Examples of Plant Breeders' Rights Licensing and Smallholder Farmers' Access to Seeds in Kenya}

In this section, three examples of plant breeders' rights licenses in Kenya are described. One example concerns development of a water efficient maize variety. This variety targets smallholder farmers in five African countries (including Kenya). The other two examples concern seed potato deployment for smallholder farmers. Each example exhibits strong commercial breeder company involvement, and registration of plant breeders' rights either in Kenya or in other jurisdictions. Further, in each example, a specific licensing strategy aimed at facilitating access of seed and planting material to smallholder farmers who cannot afford to pay full commercial prices is observed.

\subsection{Maize- The Water Efficient Maize for Africa project (WEMA)}

WEMA is a public private partnership with a charitable objective. It is funded by the Bill and Melinda Gates Foundation, the Howard G. Buffett Foundation and, the US Agency for International Development (USAID) and led by the African Agricultural Technology Foundation (AATF). AATF is a not-for profit organisation that facilitates and promotes public private partnerships for the access and delivery of appropriate agricultural technologies for sustainable use by smallholder farmers in sub-Saharan Africa. WEMA project partners include Monsanto, a US-based agrochemical and agricultural biotechnology corporation. Monsanto is donating its commercial drought-tolerance and insect-protection traits royalty free to the consortium. The International Maize and Wheat Improvement Centre (CIMMYT) a CGIAR Centre, and the national agricultural research centres from Kenya, Mozambique, South Africa, Tanzania and Uganda are also in the research consortium. The project seeks to develop and deliver conventionally bred or genetically modified maize varieties with improved drought tolerance and/or insect resistance to smallholder farmers in South Africa, and to the rest of sub-Saharan Africa (Note 9).

Conventionally bred water efficient hybrid varieties from the project are already available for licensing in Kenya, Uganda, Tanzania and South Africa. However, due to biosafety regulatory requirements, genetically modified drought tolerant hybrid maize varieties in the project are undergoing confined field trials in the partner countries, with each country evaluating whether these varieties are suitable for their drought or insect conditions. An application for environmental release of the insect protection event has also been filed in Kenya.

A number of IPRs are being deployed in the WEMA project. First, the drought tolerant trait is patented in South Africa. Secondly, consideration is being made to apply for plant breeders' rights on the improved conventional lines in some of the project countries that have functional plant breeders' rights laws in place. Further, AATF has also registered trademarks in the partner countries, as WEMA varieties will be commercialized in all countries under a single brand-DroughtTEGO ${ }^{\text {TM }}$.

The main licensing strategy in this project is delivery of seed to the targeted farmers on a royalty free basis. Here, targeted farmers have been defined as "farmers in South Africa who plant up to three hectares of land for the production of maize and all farmers in the rest of sub-Saharan Africa." As such, parties involved in WEMA-the licensed companies and seed producers will not collect or receive a royalty from the farmers, the idea being to minimize the costs of seed to farmers (Note 10). However, there is recognition that some of the technology 
innovation that may be developed could have considerable commercial value for large-scale farmers in South Africa and outside Africa. It is for this reason that the target project beneficiary is delineated to exclude commercial farmers in South Africa. These farmers will access the technology at full commercial scale, subject to conditions yet to be determined as the project's current focus is reaching the target farmers.

\subsection{Potato-HZPC, Kisima Farm and Syngenta Foundation for Sustainable Development}

This example involves three actors-HZPC, a seed potato company based in the Netherlands exporting seed potato to most parts of the world; Kisima Farm, a private Kenyan seed potato multiplier; and, Syngenta Foundation for Sustainable Development, a not-for-profit organization. This not-for-profit organization is established by Syngenta AG, a global agrochemicals and seed company. It aims to work with pre-commercial farmers- a term used by the Foundation to refer to small-scale producers, with a view to create value for them through innovation in sustainable agriculture and the activation of value chains.

The main activity herein is the introduction of new potato varieties in Kenya by HZPC through Kisima Farm, with Syngenta Foundation facilitating the licensing discussions of these varieties between HZPC and Kisima Farm, and the actual introduction of the varieties into Kenya.

While the Kenyan market for potato processing varieties (Note 11) appears promising for HZPC due to an emerging middle class, the company has so far not been ready to introduce these varieties. This has been due to the fact that in the company's view, the Kenyan potato market value-chain is not well co-ordinated and there is rampant saving of seed by smallholder farmers. This is not the case in northern Africa - Egypt, Tunisia and Libya where HZPC is also operating in. According to HZPC, the potato market value chains in these countries are well-organised and seed savings and re-use by farmers is not as rampant. As such in HZPC's view, the cost of enforcing plant breeders' rights would be higher in Kenya than in these other African countries, yet the company would not wish to be seen to be harassing smallholder farmers.

HZPC had up to July 2015, officially released nine varieties into the Kenyan market besides applying for plant breeders' rights on the same (KEPHIS, 2015).

Notwithstanding the plant breeders' rights applications, the main licensing strategy that HZPC is pursuing is foregoing royalties with respect to the seed bulked and multiplied of the processing varieties it is introducing.

Every cropping season, Kisima Farm purchases in vitro potato tubers from HZPC, which through an aeroponics system produces microtubers. The microtubers are thereafter transferred to the seed farm for reproduction and bulking. This takes up to three cycles whereafter the seed produced is sold to farmers. HZPC only collects a royalty on the in vitro potato tubers, which royalty is built into the purchase price and does not concern itself with the seed quantities that are bulked and multiplied for sale to farmers (Note 12). According to Barker (2013) the licence arrangement between HZPC and Kisima Farm thus permits Kisima Farm to commercially produce seed of modern processing varieties in Kenya in return for a one-time only royalty payment and a waiver of right to collect seed multiplication royalties from Kisima and re-plant fees (farmer fees otherwise collectible from farm saved seeds).

The approach by HZPC, Kisima Farm and Syngenta Foundation puts smallholder farmers in an advantageous position as the agreement to waive the right to collect seed multiplication royalties and re-plant fees enables the cost of access to seed by farmers to be at a minimum. While farmers are free to use farm-saved seed they are encouraged to purchase new seed every season due to quality issues. HZPC is not necessarily turning a profit in this arrangement. However, it has gained a position in the Kenya market whereby the company is able to study the potato value chain and weigh the potential for introducing its other varieties that are not part of the current arrangement.

\subsection{Potato- Mayan Gold Case}

Mayan Gold is a potato variety originally bred in the United Kingdom by James Hutton Institute- formerly the Scottish Crop Research Institute (SCRI), a public research institution. Amongst its attributes is resistance to late blight on foliage (Phytophthora infestans), powdery scab (Spongospora subterranean) and potato T. tricovirus and potato leafroll virus. Further it has low dormancy and as such can be cropped twice a year; fast cooking time thereby saving charcoal and wood fuel; and, resistance to bruising and splitting thus increased yields.

A research grant by the Monsanto Fund, a charity formed by Monsanto Co. has enabled James Hutton Institute, Greenvale Plc-a licensee of the variety, and Masinde Muliro University of Science and Technology (MMUST)- a Kenya public university, through an agreement to undertake research in Kenya evaluating the variety on its susceptibility to a number of potato diseases. Following the National Performance Trials, Mayan Gold was officially released in Kenya in June 2014 (Government of Kenya, 2014). 
One of the conditions contained in the agreement between the parties on the research over the variety in Kenya is that the variety shall be made available in Kenya on a not-for-profit basis. This condition has been carried over from the agreement and included as one of the variety conditions, in the national variety release register (Government of Kenya, 2014). To put a regulatory condition that seed should only be made available to farmers on a not-for-profit basis is innovative. Not only is making the seed of the released variety available on a commercial basis an infringement of the agreement, but also of variety release conditions. This effectively transfers the costs of enforcing the agreement from the parties to public authorities.

It is notable that in the UK and other parts of the world, this potato variety is available on full commercial scale. However, as notable in the Kenya Gazette releasing the variety the parties have agreed that the variety shall not be available to the Kenyan farmers on commercial terms. This does not mean that the variety will be available to the farmers for free, but rather, that the price the farmers will pay for the seed will only be sufficient to meet its production costs. As at the time research was undertaken, the price was yet to be set as the variety is currently being multiplied at the Kenya Agricultural and Livestock Research Organisation (KALRO), and at the Agricultural Development Corporation- a public seed multiplier. It was expected that the varieties will be available to the farmers from 2017.

Whereas plant breeders' rights on Mayan Gold have been taken out in the UK and other parts of the world, in Kenya plant breeders' rights have not been applied for either by the licensee or licensors. The agreement to have the variety availed to farmers on a not-for-profit basis precludes the possibility of third parties offering the variety to farmers on commercial terms. This is then expected to lower the cost of production of the variety and thereby seed purchase price for the farmers. Furthermore, MMUST acknowledges that once Mayan Gold is available to farmers, they may well save and re-use seeds of the variety. MMUST cannot, and does not intend to explicitly restrict farmers from saving and re-using the seed of the improved variety. Moreover, it is hoped that the net result will be a reduction on costs of accessing seed which in itself will encourage farmers to purchase new and, thus, clean planting material after every cropping cycle rather than save and re-use from their own harvests.

The three examples described above concern breeding efforts whose results are aimed to (also) reach smallholder farmers. The next section discusses some observations on the plant breeders' rights licensing strategies that emerge from these three cases, and reflects on the question whether and how licensing can be used as a mechanism to facilitate access to seeds and planting material for smallholder farmers.

\section{Reflections on Licensing as a Tool to Facilitate Access to Seeds for Smallholder Farmers}

\subsection{Observations on the Three Licensing Strategies Utilised}

A number of observations on the licensing strategies utilised emerge from the three examples described above.

One important observation is that all three examples apply some form of market differentiation. Market differentiation is an important consideration in order to ensure that the target beneficiary- the smallholder farmer is reached. Hence in the WEMA case, the target farmer is defined in a manner to exclude commercial farmers in South Africa; in the Mayan Gold case, the variety is released on a not-for-profit condition only in the Kenyan market; and, in the HZPC case, only a select number of varieties suitable for the market discerned by the breeder have been made available under the arrangement in place. The process of differentiating the market involves understanding and defining the characteristics of the targeted beneficiary-recipient farmer, by the right holder.

The differentiation of market conditions in these three cases exhibit characteristics of what in patents licensing is known as humanitarian use licensing. Humanitarian use licensing has come about in order to deal with transfer of technology- in particular pharmaceuticals to developing countries, which has become more problematic due to among others, research inputs and outputs being protected by patents and unaffordable for the poor (Spillane, 2002). Thus to overcome problems caused by patents, creative and novel technology transfer mechanisms-such as market differentiation combined with reduced or royalty free licensing, have been developed. The creativity and novelty lies in the fact that these mechanisms reconcile poor peoples' access to new technologies with proprietors' ability to maintain control over their technology and reap a return on their investment in more profitable markets (Lybbert, 2002).

Whereas humanitarian use licensing strategies have received considerable attention in the field of pharmaceuticals as a tool to facilitate access to medicine for the poor, this is much less the case in the agricultural sector (De Jonge, Tumushabe, Barungi \& Louwaars, 2010). A notable exception is the Golden Rice case, which has broadly advertised the humanitarian use licensing strategy of the technology. In this case, the inventors of the technology assigned their exclusive rights to Syngenta, which also negotiated licences with other 
companies to use supplementary technologies needed to create Golden Rice. While maintaining the commercial rights (although, at a later stage, the plans to commercialise Golden Rice were abandoned), Syngenta has given the inventors a humanitarian licence to the full set of technologies with the right to sublicence public research organisations and low-income farmers in developing countries (Note 13). However, this example concerns patent protected technologies in particular.

The WEMA project provides an apt example of humanitarian use licensing in the field of plant breeders' rights, and applies a clear differentiation between its target beneficiaries and the commercial market. However, the project appears to be lagging behind in putting in place mechanisms to determine terms and conditions for which the untargeted farmers (Note 14) will access varieties. It is important for both the humanitarian use and the commercial markets to be considered in tandem so that a delay does not arise in realization of profits that could otherwise be obtained by making the improved varieties available to the commercial market. Such profits earned could invariably be used to support the humanitarian use market, ploughed back into research or simply repatriated by the parties involved for their shareholders. The two seed potato case studies appear to be satisfying their commercial objectives in other markets outside Kenya already (Note 15). Presumably then, in these two seed potato cases, they have already made considerations in differentiation between the under-served Kenyan farmers and commercial farmers outside Kenya. Another reason to carefully consider both markets in tandem is because the release of improved varieties to the targeted farmers may carry with it the risk of these seeds finding their way to commercial farmers without there being in place mechanisms to deal with such situations.

Considering these factors, it is interesting to look at the licensing strategies of the other two cases. In the Mayan Gold case, for example, the parties involved differentiate the market by applying for plant breeders' rights in some countries and not in others. Not taking out plant breeders' rights coupled with the parties agreeing to not-for-profit conditions which are thereafter embedded on to national variety release procedures appear to be the main strategy. Not taking out plant breeders' rights obviously reduces the costs attendant to maintaining the variety whereas embedding agreed conditions to national variety release procedures has the effect of transferring enforcement costs from the parties to the public authorities. These two elements enable seed multiplication arrangements to be put in place in a way that ensures that seed ultimately reaches a farmer at the least cost possible.

Another approach is applied by HZPC, whose licensing strategy is mainly about waiving some if its rights against seed producers and farmers. While HZPC is aware that smallholder farmers will save, re-use and exchange harvests from their protected varieties, the company will neither prevent farmers from doing so nor claim reasonable compensation from them. This is notwithstanding that the company has a right to do so as under the Kenya plant breeders' rights law farmers are only allowed to use farm-saved seed on their own holding, within reasonable limits and subject to safeguarding the legitimate interests of the breeder (Note 16). The option by HZPC to only collect royalties from the sale of in vitro potato tubers and waive seed multiplication royalties on the amount of propagation material produced and sold to the farmers is obviously of benefit to the farmers as well. In this way, the price of seed is kept to a minimum.

Before comparing the pros and cons of these various licensing strategies, it is important to notice, as described in section 2, how the different types of crops and the seed systems they operate in influence the licensing strategies that breeders deploy. In the WEMA case, the maize varieties are all hybrids. Since the yielding capacity of farm-saved hybrid seed is significantly lower than the original seed, farmers prefer to buy new seed for every cropping season. In order to facilitate access, the WEMA parties aim for the delivery of seed to be multiplied by companies in each project country for the targeted farmers on a royalty free basis. Potato is vegetatively propagated which means that seed production is very easy and farm-saved seed, despite an increased probability of getting diseased, will maintain its qualities and yielding capacity. Therefore, to facilitate access to seed, potato breeders may simply allow smallholder farmers to use and exchange farm-saved seed of a protected variety, a strategy that cannot equally be applied in the case of hybrids.

Another observation is that plant breeders' rights are not necessarily the only IPR tool that a breeder may deploy in order to facilitate access of seed to smallholder farmers. From the WEMA case, it can be discerned that trademarks are also important IPR tools both to farmers and breeders. Trademarks enable farmers to easily identify and differentiate seeds in a market and in the process also build the breeder's market reputation (Note 17).

\subsection{Advantages and Disadvantages of the Main Plant Breeders'Rights Licensing Strategies}

From the licensing examples discussed above, one can extrapolate three main strategies a breeder can utilise in order to facilitate smallholder farmers' access to a new variety. These can be summarised as follows: 
- Not applying for plant breeders' rights in a particular country;

- Taking out plant breeders' rights and waive some rights in subsequent licenses;

- Taking out plant breeders' rights and applying a humanitarian use licensing strategy.

Whereas this article focuses on licensing of plant breeders' rights, it must be acknowledged that a right holder may also choose to simply not enforce its rights on smallholder farmers without explicitly waiving its rights or including humanitarian use provisions in its licenses. Actually, many right holders may probably do so on a daily basis, as it simply makes no business sense to spend time and resources on enforcing plant breeders' rights on those smallholder farmers whose farming practices do not target commercial markets. Yet, the downside of this approach is that without a formal waiver of rights, smallholder farmers that use and, in particular, exchange or trade farm-saved seed of a protected variety will likely be in breach of the national plant breeders' rights law (Note 18).

This may have varying consequences, depending on the country in question. In many countries, plant breeders' rights fall under private law, which means that the responsibility for enforcement of the breeders' rights is left to the right holder itself. This implies that smallholder farmers do not run any risks under the plant breeders' rights law if the breeder decides not to enforce its rights on them. By publishing such policy on its website, a breeder would both create legal certainty for smallholder farmers and improve its public image.

Few countries, however, have introduced criminal law provisions in their plant breeders' rights law to specify protection measures against infringements. Section 34 of the Tanzanian 2012 Plant Breeders' Rights Act, for example, specifies that "Breeders' rights are protected by both civil and criminal law measures stipulated in any written law". This implies that smallholder farmers can be prosecuted irrespective of a right holder deciding not to enforce its breeders' rights on them. In Kenya, the plant breeders' rights legislation contains general criminal provisions relating to enabling public authorities undertake actions such as inspections and prevention of provision of false information to the public authorities. However, the anti-counterfeiting law-the Anti-Counterfeit Act, 2008 defines counterfeiting so liberally to include certain activities against goods protected by plant breeders' rights, which essentially are, plant varieties. This means that all offences in relation to counterfeit goods, such as selling, possession, barter or exchange, apply to plant varieties as well (Note 19).

Turning back to the three main strategies listed above, a brief discuss of their main advantages and disadvantages follows.

The main advantage of the first strategy- not applying for plant breeders' rights, is probably that it is the cheapest of the three as it precludes plant breeders' rights application, maintenance and enforcement costs. For breeding programs that first and foremost target smallholder farmers in developing countries, this strategy is likely to be the most attractive. This observation is confirmed by, for example, the very low number of plant breeders' rights applications applied for by the international agricultural research centres of the CGIAR (Note 20).

An important disadvantage is that the breeder has few instruments to control the use of its variety in the marketplace. For example, it may be difficult to incentivize seed companies to multiply and market the variety if no market exclusivity can be provided.

The second strategy- waiving of some plant breeders' rights, does provide the breeder with control over its variety in the marketplace. This position allows the right holder to decide on the best marketing strategy. By waiving its rights to collect seed multiplication royalties from the seed producer, HZPC aims to keep the seed price to a minimum. By doing so, HZPC hopes that farmers start buying new and clean planting material every cropping season. In a seed system where seed saving, re-use and exchange by farmers is rampant, this is a first and crucial step towards building a viable seed business. An added advantage of this licensing strategy, together with the waiver for farmer re-plant fees, is that it enhances the companies' reputation while allowing the company to obtain a market position and a better understanding of the Kenyan seed potato market.

The main disadvantage relates to the costs involved. Next to the costs of applying and maintaining the plant breeders' right, licensing involves other costs in the form of time and resources that need to be invested in negotiating, monitoring and implementing the licence conditions. Normally, these costs are divided over the various parties to the licence, and all expect to make a return on their investments in the market place. However, when the market is composed of smallholder farmers who predominantly access seed through informal channels, neither the licensor nor the licensee are likely to make a profit from the arrangement or even recoup their licensing costs. As demonstrated in the three cases, this has brought forth a third set of entities into the process. This third set consists of not-for-profit technology facilitators or brokers- AATF; Monsanto Fund; and, Syngenta Foundation for Sustainable Development with their role being to link the licensor and licensees and in the 
process, absorb some or all of these costs on behalf of the parties.

The third strategy- humanitarian use licensing, can be a tool to mitigate the costs of providing for the non-commercial market by simultaneously protecting and exploiting one's rights in commercial markets. Experiences drawn from humanitarian use licensing in respect of pharmaceuticals suggest that universities and companies alike can facilitate access to medicine in developing countries without this "loss of market share in the developing world [to] diminish the company's value" (Stevens, 2008). Yet, these lessons cannot easily be extrapolated to the agricultural sector for various reasons. One is the fact that a new variety cannot be marketed across the globe but needs to be adapted to local environments. Also, the market value of most crops is significantly smaller than of pharmaceuticals not only in developed countries, but globally as well. In 2011, the ISF estimated the global seed industry to be valued at USD 45 billion while IMS Health estimated the pharmaceutical market value at USD 956 billion. During the same period, Kenya's domestic seed market was estimated by the ISF to be worth USD 60 million against IMS Health estimate of the domestic pharmaceutical market at USD 659 million.

Whether a humanitarian use licensing strategy with respect to a protected variety would indeed allow the licensor to mitigate its costs and recoup investments depends, amongst others, on how effectively the strategy separates humanitarian from commercial use. A repeated concern is that low priced versions of a product may undermine sales of the same in the commercial market. Putting in place legal and practical mechanisms to keep markets apart always come with a price and that may be the main reason why humanitarian use licensing has hardly been applied in the agricultural sector, and when it is, the licensing strategy is often sponsored by a philanthropic organisation as in the three cases described above.

Despite the costs, there may also be advantages to applying a humanitarian use licensing strategy. One is the aforementioned public image gain, as the strategy can be used to show a licensor's social responsibility and increase its reputation. Another advantage is that through market differentiation, a right holder can provide clarity on the various conditions to which different groups of farmers can make use of its variety. This can be useful especially in countries like Kenya where despite there being a farmers' privilege in the law, the same is not implemented through regulation. For example, next to spelling out the category of farmers that can access the variety on a royalty-free basis, the licensor can clearly define the conditions for royalty payments on the use of farm-saved seed for commercial farmers.

\section{Conclusion}

As a tool to transfer technology and inventions between parties and across geographies, licensing has not received much attention in plant breeders' rights especially in market conditions that predominantly involve smallholder farmers such as those found in Kenya. When licensing is deployed in plant breeders' rights generally, there are a number of factors that come into play. These factors include the general legal structure of the national plant breeders' rights system and the source of, and, policies attendant to the income of the breeder. Also key are the type and market of crop, including the seed system operating as well as the royalties collection mechanisms that may be available to the breeder.

Kenya's plant breeders' rights system is based on UPOV 1978 and was recently the subject of efforts to upgrade the same to the UPOV 1991 standards. As observed, these standards were not met to the letter, mostly by the omission of the private and non-commercial use exception. No specific policies that could explicitly dictate the licensing conditions exist at the national level as well. Farmer based seed systems in which smallholder farming is key, are dominant in the food crops sector. This is the background against which licensing in plant breeders' rights is taking place.

From the three licensing cases described in this article, market differentiation emerges as a key issue in licensing in market conditions such as those prevailing in Kenya. Market differentiation enables the breeder to identify the targeted beneficiary in licensing. The type of crops the subject of the licence -whether hybrids or vegetatively propagated crops also influence specific strategies that may be deployed. It is also observed that not taking out plant breeders' rights also constitutes part of the strategy, as also taking out plant breeders' rights. Where plant breeders' rights are taken out, breeders either also opt to waive their rights in some of their subsequent licences or employ humanitarian use licensing in their strategies to enable seed reach smallholder farmers. While licensing of plant breeders' rights in market conditions such as those prevailing in Kenya has some advantages, the main disadvantage relates to costs. This is the case as the market is hardly sufficient to enable all parties recoup their investment costs. This has brought about not-for-profit third party technology facilitators or brokers who bear some of the costs associated with the licenses.

The use of licensing as a tool to facilitate access to seed and planting material for smallholder farmers in market 
conditions such as those prevailing in Kenya, appears limited to very few crops. Given that markets such as those in Kenya are dominated by smallholder farmers, who can ill-afford to pay for seeds at market prices this diminishes the possibility for breeders being able to recoup costs attendant to enabling seed and planting materials reach the smallholder farmers market. This has brought about the emergence of not-for-profit technology brokers in the licensing field. Breeders where they consider as part of their licensing strategy to smallholder farmers, a waiver of some of their rights with respect to protected varieties, should publicly provide this information. This way the specific category of farmers for which activities such as seed saving, exchanging and re-using is permissible despite the law providing otherwise will remain known.

\section{References}

Ayieko, W. A., \& Tschirely, D. L. (2006). Enhancing Access and Utilization of Quality Seed for improved Food Security in Kenya. Tegemeo Institute of Agricultural Policy and Development. Retrieved December 2, 2013, from http://www.tegemeo.org/images/downloads/Working\%20papers/tegemeo_workingpaper_27.pdf

Curtis, F., \& Nilsson, M. (2012). Collection Systems for Royalties in Wheat: an international study. Bio-Science Law Review, 1(6).

De Jonge, B., Tumushabe, G., Barungi, J., \& Louwaars, N. (n.d.). Agricultural seeds that reduce hunger and poverty-policies, perceptions and practices in intellectual property rights. In W. van Genugten, \& A. Meijknecht (Eds.), Harnessing Intellectual Property Rights for Development Objectives: The double role of IPRs in the context if facilitating MDGs Nos. 1 and 6. Wolf Legal Publishers, Nijmegen.

Devarajan, S., \& Kasekende, L. (2011). Africa and the global economic crisis: Impacts, policy resources an political economy. African Development Review, 23, 421-438. https://doi.org/10.1111/j.1467-8268.2011.00296.x

Government of Kenya, Kenya Gazette Notice No. 4711 dated 14 June 2014 (Vol. CXVI-No. 80).

Graff, G. D., \& Bennett, A. B. (2007). Intellectual Property and Technology Transfer by the University of California Agricultural Experiment Station. In A. Krattiger et al. (Eds.), Intellectual Property Management in Health and Agricultural Innovation: A Handbook of Best Practices. MIHR: Oxford, UK, and PIPRA: Davis, California.

Ian Barker submission to the $10^{\text {th }}$ Meeting of the CGIAR Fund Council -Novemebr 6 and 7, 2013 in Nairobi titled, Scaling Technology Transfer through Private Seed Channels: Experience from East Africa. Also see-Kisima, CIP and Syngenta Foundation for sustainable Agriculture (2014), Potato seed impact study report: interim study report on the impact of adopting certified potato seed in Meru County Kenya (2011-2014).

Kaul, I., Grunberg, I., \& Stern, M. A. (1999). Global Public Goods: International Cooperation in the $21^{\text {st }}$ Century. UNDP, UN Plaza, New York. https://doi.org/10.1093/0195130529.001.0001

Kenya Plant Health Inspectorate Service. Kenya National Crop Variety List, July 2015.

Louwaars, N., Dons, H., van Overwalle, G., Raven, H., Arundel, A., Eaton, D., \& Nelis, A. (2009). Breeding Business: The future of plant breeding in the light of developments in patent rights and plant breeder's rights. CGN Report 2009-14(EN).

Lybbert, T. J. (2002). Technology Transfer for Humanitarian Use: Economic Issues and Market Segmentation Approaches. IP Strategy Today, (5), 17, 25.

Munyi, P. (2015). Plant Variety Protection Regime in Relation to Relevant International Obligations: Implications for Smallholder Farmers in Kenya. The Journal of World Intellectual Property, 18, 65-85. https://doi.org/10.1111/jwip.12031

Munyi, P., \& Jonge, B. De. (2015). Seed systems support in Kenya: Consideration for an Integrated Seed Sector Development Approach. Journal of Sustainable Development, 8(2). https://doi.org/10.5539/jsd.v8n2p161

Muraguri, L. (2010). The role of intellectual property in agricultural public-private partnerships in the context of development. An unpublished thesis submitted in partial fulfilment of the requirements for the degree of Doctor Philosophy in Law, University of London.

Payumo, J. G., Grimes, H. D., \& Jones, K. J. (2012). Licensing agricultural intellectual property: how should public R\&D institutions in developing countries respond? International Journal of Innovation and technology Management, 9(4). https://doi.org/10.1142/S0219877012500289

Rangnekar, D. (2006). Assessing the economic implications of different models for implementing the requirement 
to protect plant varieties: A case study of Kenya. A report prepared under the European Commission's $6^{\text {th }}$ Framework Programme for Research (Contract No.503613) as part of the Project: Impacts of the IPR Rules on Sustainable development.

Setimela, P. S., \& Kosina, P. (Eds.). (2006). Strategies for Strengthening and Scaling up Community-based Seed Production. Mexico, D.F.:CIMMYT.

Spillane, C. (2002). Agricultural biotechnology and developing countries: proprietary knowledge and diffusion of benefits. In T. Swanson (Ed.), Biotechnology, agriculture and the developing world: the distributional implications of technological change. Cheltenham: Edward Elgar. https://doi.org/10.4337/9781843767435.00013

Stevens, A. J., \& Effort, E. A. (2008, June). Using Academic License Agreements To Promote Global Social Responsibility. Les Nouvelles, 99.

Thomson, R. (2013). The yield of plant variety protection. Intellectual Property Research Institute of Australia Working Paper No. 6/13.

Thornstrom, C. G., Virgin, I., Thorn, E., \& Ericsson, M. (2013). Science, Genetic Resources and Regulation. Sida ITP-Program Final Report: The GRIP experience 2003-2014 with focus on GRIP-12 and 13. SLU and Sida.

\section{Notes}

Note 1. While Kenya has had a plant breeders' rights regime since 1972, the same was not implemented until 1996 enabling the first application relating to a rose variety, to be made. South Africa's plant breeders' rights registration system has been in place since 1976 and had as at 8 October 2014, 2,607 grants in its register, compared to Kenya's 317; Morocco's 217; and, Tunisia's 113. See UPOV document C/48/7 dated 8 October 2014.

Note 2. This is an optional exemption within the UPOV 1991 Convention and included in most plant breeders' rights laws of the countries that are member to this convention. The exemption is only meant for crops "where, for the member of the Union concerned, there was a common practice of farmers saving harvested material for further propagation." See document UPOV/EXN/EXC/1 of 22 October 2009.

Note 3. The farmers' privilege has been implemented in the European Union through Commission Regulation (EC) No. 1768/95. With the exception for a defined category of small farmers, others who save and re-use seeds of a protected variety from their own harvests must pay remuneration to the breeder. The amount of the remuneration has to be agreed upon between the breeder and the farmer (or his representative), and in the absence of an agreement, this has been set at $50 \%$ of the royalty normally included in the seed price.

Note 4. KEPHIS was originally established in 1996 through a regulation - the Kenya Plant Health Inspectorate Order, 1996. This regulation is set to be repealed by the Kenya Plant Health Inspectorate Service Act, 2012 (Act No. 54 of 2012) which is yet to come into force.

Note 5. The Arusha Protocol for the Protection of New Varieties of Plants was adopted in July 2015. It will come into force one year after it receives four ratifications or accessions. It is open for signature until 31 December 2015. As at 1 October 2015, five countries had signed the Protocol but none had ratified.

Note 6. HZPC and Agrico's communication to the authors.

Note 7. This does not mean that seeds are given out for free, but rather the breeder does not charge any royalty fees from the licensees.

Note 8. CRS-GLCI communication with the authors.

Note 9. In the project, smallholder farmers in South Africa are defined as those who plant maize in up to three hectares.

Note 10. Information available from WEMA website.

Note 11. These are potato varieties used for processing either as chips or fries as opposed to ware or table varieties which are used for mashing or cooking in other ways.

Note 12. Communication by Kisima Farm to the authors.

Note 13. Humanitarian use was defined as (i) use in developing countries (low-income, food-deficit countries as defined by the FAO) (ii) resource-poor farmer use (earning less that USD $\$ 10,000$ per year from farming) (iii) 
the technology must be introduced into public germplasm only (iv) national sales are allowed by low-income farmers (in this way urban needs are also covered) (v) reusing the harvested grain as seed for the following season is allowed (the farmer is deemed to be owner of his seeds). See http://www.goldenrice.org/Content1-Who/who4_IP.php

Note 14. These are farmers in South Africa who plant maize in more than three hectares of land, and farmers in the rest of the world outside Sub-Saharan Africa. Most large scale or commercial farmers in South Africa already have access to such varieties. According to AATF, most large scale or commercial farmers in South Africa already have access to such varieties. However, the problem might be with those South African farmers farming more than 3 hectares but who are not exactly large scale or commercial farmers.

Note 15. A perusal of the 2012 and 2013 Reports and Financial Statements of Produce Investments plc, whose subsidiary -Greenvale owns Mayan Gold, and HZPC Holland BV indicate that these entities made profits, and there is no loss that occurred or was attributed to a particular variety.

Note 16. Section 20 of the Seeds and Plant Varieties Act, 1972 as amended by section 17 of the Seeds and Plant Varieties (Amendment) Act, 2012.

Note 17. In addition, the cost of acquiring trademarks rights is much less than that of acquiring PVP. Furthermore, trademarks rights unlike PVP remain available to the breeder as long as the trademark is in use and as such, there is no risk of expiry of the rights unless the breeder ceases to use the mark

Note 18. It must be noted that some farming practices like the exchange and trade of farm-saved may also be governed by other laws than plant breeders' rights such as seed certification regulations.

Note 19. Section 2 of the Anti-Counterfeit Act, 2008 defines counterfeiting to include the manufacture, production or making, whether in Kenya or elsewhere, the subject matter of that intellectual property without the authority of the owner of intellectual property subsisting in Kenya, with intellectual property right being said to include plant breeders' rights.

Note 20. No CGIAR centre applied for plant variety protection in the period 2012-2014. During this period, only three centres entered into an agreement with third parties containing provisions authorizing the third party to apply for PVP in specific countries. See Intellectual Assets Report for Year 2013, prepared by the CGIAR Consortium Office and the Fund Council IP Group.

\section{Copyrights}

Copyright for this article is retained by the author(s), with first publication rights granted to the journal.

This is an open-access article distributed under the terms and conditions of the Creative Commons Attribution license (http://creativecommons.org/licenses/by/4.0/). 